\title{
Lumen
}

Selected Proceedings from the Canadian Society for Eighteenth-Century Studies

\section{Thomas Walker's Ear: Political Legitimacy in Post-Conquest Quebec}

\section{Carolee Pollock}

Volume 19, 2000

Material Productions \& Cultural Construction

Culture matérielle \& Constructions discursives

URI : https://id.erudit.org/iderudit/1012325ar

DOI : https://doi.org/10.7202/1012325ar

Aller au sommaire du numéro

Éditeur(s)

Canadian Society for Eighteenth-Century Studies / Société canadienne d'étude du dix-huitième siècle

ISSN

1209-3696 (imprimé)

1927-8284 (numérique)

Découvrir la revue

Citer cet article

Pollock, C. (2000). Thomas Walker's Ear: Political Legitimacy in Post-Conquest Quebec. Lumen, 19, 203-214. https://doi.org/10.7202/1012325ar

Copyright (c) Canadian Society for Eighteenth-Century Studies / Sociéte canadienne d'étude du dix-huitième siècle, 2000
Ce document est protégé par la loi sur le droit d'auteur. L'utilisation des services d'Érudit (y compris la reproduction) est assujettie à sa politique d'utilisation que vous pouvez consulter en ligne.

https://apropos.erudit.org/fr/usagers/politique-dutilisation/ 


\section{Thomas Walker's Ear: Political Legitimacy in Post-Conquest Quebec}

Thomas Walker was sitting at his supper table in Montreal on December 6th, 1764 when several armed men burst into the room. His wife Martha fled through the kitchen to the cow house. From there she sent the apprentice boy to see what was happening. He reported, 'oh madam my master is all over blood.' Martha ran into the house and found, 'Mr Walker sitting upon the Floor so covered with Blood that it was impossible to have known him.' She asked her husband, 'shall you die?' to which he replied, 'I believe not get me a surgeon.'

Thomas Walker's assailants beat him badly and cut off his ear and part of his cheek. Thomas Ainslie described Walker's condition: 'As for his Body, it is one continued piece of Mummy beat as if with railles till it is as black as a hatt \& so swelled that you barely can know the remains of his face or the Colour of his skin.'

Who was Thomas Walker and who assaulted him so violently? And why? Walker was a substantial merchant and a newly appointed Justice of the Peace, appointed as part of the process of replacing the British military rule that had held in the colony since 1760 with a civil administration. The colony had been ceded to the British by France in the Treaty of Paris in 1763. Walker was not attacked by the French inhabitants, as one might expect, but by soldiers of the 28th Regiment of the British army. Why he was attacked is a little more complicated.

The attack on Walker shows the difficulties faced by the British colonial administrators in establishing a legitimate civil administration in the colony. They planned to create a civil government for Quebec on the model of British constitution. In fact, they had promised to do so in the Royal Proclamation of 1763. But the significant challenges posed by the colonial situation - particularly the facts that the Canadiens were Catholic and under British law at the time and that Catholics could not participate in civil government - forced them to adapt and modify the metropolitan model. When General James Murray, who had been the military governor of the district of Quebec since 1759, became the first civilian governor of the new colony, he undertook to govern some 70,000 
French Catholics and maybe 300 or so English-speaking merchants who had followed the army to Quebec and hoped to make their fortunes there.

But the King required many more servants than a governor alone to administer the colony - Council members, officials, even Justices of the Peace, were necessary to a civil administration. This proved to be one of the most insuperable of the challenges faced by the governors of the colony. The colony simply did not contain enough of the right people to fill the positions necessary for a smoothly functioning British administration. Why not? First, as already stated, the Catholicism of the Canadiens excluded them from participation. ${ }^{3}$ Second, the Protestants who did reside in the colony, the English-speaking merchants and the military men, were not the right sort of people - they were not men of property. Governor Murray complained to his superiors in London of his difficulties in appointing men to civil offices. Few of the old British subjects in the colony had acquired property and 'consequently cannot be supposed thoroughly attached to its Interests. ${ }^{4}$ Landed men were what the colony lacked, at least landed men who could take civil office. Thus, Thomas Walker, a merchant with his fortune to make, was appointed to the magistracy, but he could not command the respect that would enable him to carry out his duties. Neither the officers nor the soldiers of the 28th Regiment were restrained from attacking him by respect for the dignity of his position. He lacked the traditional sources of legitimacy as Justice of the Peace - landed property, title or standing in the community.

The affair of Thomas Walker's ear, when set within the context of the political struggles between the merchants in the colony and its Governor, shows the different perceptions of the nature of the British constitution they held and the difficulties the Governor had in establishing a legitimate civil administration in the colony. The colonial administrators' vision of the state was paternalistic, monarchical, hierarchical and backed by the sanction of the church: an ancien regime, in other words. Authority flowed downward from the King. It was not for nothing that governors invariably referred to the colonists as either 'His Majesty's new subjects' (the Canadiens), or 'His Majesty's old subjects' (the British merchants). The people were subjects whose duty was obedience, rather than citizens whose participation in decision-making was to be solicited. This perception contrasts sharply with the ideas that had begun to circulate in the colonies to the south and that were expressed by the English-speaking merchants in the colony - ideas concerning the sovereignty of the people and the necessity of representation to legitimate government. The merchants clamoured for a legislative assembly from which they were prepared to exclude the Catholic Canadiens without 
qualm. They regarded their own participation in governance as necessary to its legitimacy. The colonial governors resisted their demands because they believed that acceding to them would have been unjust and would have undermined the legitimacy of the colonial government in the eyes of the Canadiens. Out of pragmatism and simple justice, the governors made adjustments to the constitutional blueprint - adjustments which permitted civil rights to Catholics that would not be granted in England and Ireland until 1829. They made these adjustments over the protests of the merchants who regarded Catholic toleration as dangerous to their liberty.

Political legitimacy was contested ground in the Eighteenth Century - in Britain, France, and the American colonies. From the revolution of 1688 to the reforms of the 1830 s, the issue of what constituted legitimate authority was always in contention. Britain, profoundly shaken by regicide and civil war in the previous century, sought to work out new definitions of political legitimacy even while appealing to the 'ancient constitution' for their justification. It was not a society oriented to innovation. ${ }^{5}$ It was in the thirteen colonies in the 1760 s and 1770 s, of course, that the conflict became most acute. Even before the Revolution itself, contending definitions of legitimate authority abounded. No Taxation without Representation! Taxation No Tyranny! The slogans of the opposing camps encapsulate the debate, which was carried out in the speeches and actions of both the colonial assemblies and the British Parliament, in the political literature on both sides of the Atlantic and in the public unrest and political demonstrations of the ordinary people in London and in the colonies.

The cession of Quebec to Britain by the Treaty of Paris in 1763 made it one more arena where the contest was played out. The question of what constituted legitimate authority was posed with particular urgency in the colony of Quebec because of its unique situation. Acquired by conquest rather than by settlement, the colony's loyalty or, at least, acquiescence in the change of rule, could not be taken for granted. The British had taken the colony by force; they could not hold it by force. ${ }^{6}$ In the event of the expected renewal of war with Catholic France, how could the quiescence of the Catholic Canadiens, 'His Majesty's new subjects,' be assured? The turmoil in the colonies to the south only exacerbated the situation. To look at the question of political legitimacy in this context is to examine one of the most significant and troublesome issues of the Eighteenth Century. ${ }^{7}$

To further the Canadiens' acceptance of the legitimacy of the new regime, the Governor did his best to ensure that the King's paternal goodness towards his new subjects was known to them. The paternal care of the King has another implication, of course. The duty of the King's 
subjects was quiet submission, rather than active participation in their own governance. The Secretary of State, Lord Hillsborough, wrote to the Lieutenant Governor of Quebec, Guy Carleton, in 1768 with respect to recommendations Carleton had made for the colony. The colonists were to wait patiently, assured of the King's 'gracious Disposition to give them every Mark of His Royal Protection that they can reasonably hope for or expect' and secure in the knowledge of the King's protection. ${ }^{8}$ A little later in the colony's life, Governor Carleton quashed a colonial petition because it would be better if the changes and improvements requested 'should take their Rise from [the King's] Paternal Attention to their Interests' rather than from their demands. It would not do for the subjects to begin to think of reform as a right. It was, rather, a gift granted to his loyal subjects by their fatherly King.

If the necessary obverse of the King's paternal attention was patient submission, it was a quality that the English-speaking merchants, His Majesty's old subjects, were sadly lacking. Instead, they demanded an assembly and challenged the legitimacy of the rule by Governor and Council. It is little wonder, then, that Murray regarded them as factious, disreputable men. They challenged the social and political structure that the governor was attempting to create in the colony. They did so, in part, because they did not share the assumptions held by the elite about the nature of the polity. They saw themselves as citizens entitled to participation in their own governance rather than as mere subjects of the King.

\section{Challenging the Legitimacy of the Administration}

The Presentments of the Grand Jury of 16 October 1764 were the first major challenge to the legitimacy of the British administration of the colony. The English-speaking merchants who dominated the Grand Jury held significantly different conceptions of the political and social order than the governors did, and the Presentments are the first real glimpse of their views after the establishment of civil government. ${ }^{9}$ The Presentments are a mixed bag of recommendations and complaints, as indeed they were meant to be. Grand Juries were meant to be an inquest into the state of the community, reporting on crimes, certainly, but also on administrative problems and other concerns. The Grand Jurors of Quebec first complained that the inferior courts established in the Province were 'tiresome, litigious, and expensive to this poor colony, as they very often must be attended with the disagreeable Necessity of Appeals, \& of course many exorbitant Fees.' The courts to which the merchants here referred were the courts of the Justices of the Peace and the Court of Common Pleas established in order to adapt the British system of 
judicature to the colonial situation. Trial in the latter court was to be by jury if either party requested it, and Roman Catholics were to be allowed to sit on these juries. The Judges in this court were to determine cases 'agreeable to Equity,' until new ordinances could be passed. French laws and customs were to be allowed and Canadian advocats and proctors could practice (ibid.). By this means Murray and the Council hoped to provide for the needs of the Canadiens. The immediate introduction of English law and procedure as promised in the Proclamation of 1763 would have caused hardship for His Majesty's new subjects, they believed. This inferior court was intended as a temporary measure to ease the transition for the Canadiens.

The second complaint made by the Grand Jurors was of the great number of Justices of the Peace appointed out of so few men legally qualified. The next Presentment expanded on this. It was a waste of time to attend a court where the judge was not qualified to explain the law and 'sum up the evidence to the Jury, to prevent it's [sic] being misled by the Barristers,' the Grand Jurors contended. Together these two complaints indicate that the Justices of the Peace were not substantial enough in the eyes of the Grand Jurors to command their respect. ${ }^{10}$ Nor were the Judges appointed to the Court of Common Pleas.

The Grand Jurors next described the practice in the colonies to the south where, they said, juries were not called unless the Chief Justice presided. Taken with the previous presentment, this article shows a wariness of juries themselves. In the southern colonies, 'neither the Lives nor Liberties of His Majesty's Subjects, nor any Property above the value of $£ 3$ Sterling, are left finally to the Decision of the Justices of the Peace,' they claimed. Once again the Grand Jurors displayed their dissatisfaction with the power given to the Justices of the Peace.

They also recommended the enforcement of the Laws of England regarding Sabbath observance for which the acquisition of 'a learned Clergyman of a moral \& exemplary life, qualified to preach the Gospel in it's [sic] primitive purity, in both Languages, would be absolutely necessary.' The clergyman was to be Protestant, of course. This is not stated explicitly in this recommendation, perhaps because of the necessity of securing the signatures of the Canadien Jurors. But strict Sabbath observance was a particularly Protestant position, and the description of the necessary clergyman evoked the common criticisms of Catholic priests - he was to 'preach the Gospel in it's [sic] primitive purity,' that is, without the accretions and corruptions of Catholicism.

The next two Presentments were the most extreme: the Grand Jury proposed that, since they themselves constituted the only representative body in the colony, they should be consulted before any ordinance was made law and that they should also inspect the public accounts twice in 
the year. They here proposed that they act as the Assembly of the colony. There is more than a little irony here. Claiming their rights as British subjects to a representative Assembly, they proposed that a non-elected, self-appointed body take on the powers of that Assembly. But before we dismiss this proposal as self-serving, which it was, let us consider what it suggests. The important aspect of the Assembly in their eyes, then, was not the procedure by which it was constituted. It could be representative without being elected. It was their interests that were being ignored or overruled in the administration of the colony and they were determined that this should not be so. From their perspective, the interests of the Canadiens were being well looked after. Too well looked after, in fact, as an additional section appended to the Presentments, signed only by the English Grand Jurors and not the Canadiens, attests. They claimed that admitting Catholics as jurors was 'an open violation of our most Sacred Laws \& Liberties, \& tending to the utter Subversion of the Protestant Religion and His Majesty's Power, Authority, Right Possession of the Province to which We belong. ${ }^{11}$

The Jurors here appealed to a widely accepted assumption of the British constitution after the Glorious Revolution - that Protestantism was inextricably linked with the legitimacy of the King's rule. This section also renders the earlier wariness of juries more understandable and fits perfectly with the recommendation regarding Sabbath observance and the need for a Protestant clergyman. Roman Catholicism was a grave danger to the liberties enshrined in the British Constitution. The additional section also complained that the appointment of so many military men to the office of Justice of the Peace was unconstitutional and that only necessity could excuse 'such an unwarrantable Encroachment on the Established Maxims of a British Government.'

Almost fifty merchants signed a public letter of thanks for the Grand Jurors' 'very spirited and laudable proceedings,' so it is clear that the presentments had the approval of a significant section of the Englishspeaking population. The Canadien members of the Grand Jury later protested at length and in detail that they had not understood what they had signed. ${ }^{12}$ Considering the content of the Presentments, it seems unlikely that they would have signed them if they had understood them. Years later, Governor Frederick Haldimand described the presentments of 1764 as having 'brought an Indelible stain upon the old Subjects, \& laid the foundation of that jealousy, on the part of the New Subjects which was only done away by the Quebec Act. ${ }^{13}$

The authorities took a harsh view of the presentments. The Committee of the Privy Council recommended that the Governor communicate the King's disapproval of the Grand Jury's actions, especially of their 'abuse of the good faith of the said French Inhabitants,' and that he assure the 
Canadians that the King would 'give the utmost attention to all proper Representations' from his Canadian subjects, and would remove every just grievance. ${ }^{14}$

\section{Thomas Walker's Ear}

The next important challenge to legitimacy in the colony was the assault on Thomas Walker. Soldiers were still billeted with the inhabitants of Montreal in December of 1764 . Under the newly established civilian government, the Justices of the Peace became the officials charged with the unpleasant duty of giving billets. A number of conflicts over billets had arisen in the month of November 1764, culminating in a ridiculous dispute over a billet involving two of the newly appointed Justices of the Peace: Captain John Fraser, a retired army officer on half-pay, and Thomas Walker, a merchant. Captain Fraser had assigned two quite desirable rooms that he himself had previously occupied to Captain Payne; the landlord had rented them to another tenant in the interim and wanted Captain Payne to take other rooms in his house instead. Payne refused. Walker issued a warrant to remove Captain Payne and the fat was in the fire. It was this dispute that resulted in the attack on Walker. But the attack was the culmination of a long-standing feud between the military and the merchants. Walker had described the conflict as 'a Contention between the Military power \& the Civil Authority and a fixt design to do, under the Colour of Law, the most arbitrary Things. ${ }^{15}$ Walker went on to say that the distress of the people was universal, that the officers demanded furnished rooms, that the soldiers demanded feather beds and sheets and that they threatened 'to take the Citizens beds from under them \& turn them out of Doors. They take their Victuals from them \& sit up all Night carousing \& burning their wood \& upon the least reprimand threaten to burn them in their houses. ${ }^{16}$

Was Thomas Walker, Justice of the Peace, a champion of liberty, a hero for the people? Certainly by his own account he was. He complained that the soldiers had already been forbidden by their officers to do business with him because of his efforts to 'give due force \& Vigour to that part of the Laws and Ordinances committed to [his] charge' (ibid.). Walker may have been flattering himself but it is nonetheless significant that he made such a claim. Note also that he described himself as a defender of the 'Laws and Ordinances committed to his charge.' He made his stand in the billeting dispute on the rights of the people and on his authority as a Justice of the Peace.

Governor Murray had a different view of the conflict between the military and the civil authorities. The affair of Captain Payne's billet, 
according to Murray, had provided the Justices an opportunity of 'wreaking their resentment on the Army. ${ }^{17}$ Governor Murray, General Murray until his appointment as civilian governor of the province, had appointed Captain Fraser and Captain Mitchelson Justices of the Peace in hopes of easing some of the tension between the military and the merchants in Montreal. Murray was well aware of the conflict between the two groups and attributed it to the poor quality of the 'mercantile people' in the colony: 'Our Merchants are chiefly adventurers of mean Education or if old Traders such as have failed in other Countrys, all have their Fortunes to make, and little sollicitous about the means provided the end is obtained, such Men are by no means proper to lessen the Prejudices which Military Men naturally have for their profession. ${ }^{18} \mathrm{~A}$ military man himself, Murray shared the prejudices of the other officers against the merchants, but as civilian governor, he had to use those same merchants as the instruments of civil government.

Other reasons for the conflict existed. The merchants had chafed under the military authority, refusing to accept the decisions of military courts and taking action that was regarded as seditious to the Crown. ${ }^{19}$ Notices critical of the military government were stealthily put up at night (ibid.). These posters had a very bad effect, according to Brigadier General Burton, 'sowing principles of sedition ... giving to the New [subjects], a despicable idea of the present Government \& to the old British subjects strange notions of Licentiousness, under the mark of Liberty, \& a Desire of controuling whatever is ordered for the Good of the King's Service and the advantage of the Country' (ibid.). Burton's lament showed the erosion of the legitimacy of the military government in the eyes of the British-born colonists. It also showed a particular understanding of the role of subjects of the King. It was licentiousness to think that they should desire to control the administration of the colony. Submission to, not participation in, government was the prescribed role of subjects of the King. But the military men, Burton included, were less prepared to offer their own submission to the newly constituted civil administration.

The story of Thomas Walker's ear did not end with the assault. The civil administration did its best to find Walker's assailants, offering a reward of two hundred pounds sterling, a full pardon, and a discharge from the army to anyone who would come forward to testify. The merchants offered another three hundred pounds sterling. No one took the bait. Four soldiers were eventually arrested and jailed. They had 'two or three plates sent [to them] each meal from the house where the officers of the Regiment mess, and what wine or Whatever [they] desired from their own table' (ibid). 
Burton, whose sympathies were quite naturally with the military, wrote to Murray saying that he could not answer for the troops' behaviour, that mutiny was a possibility. The threat was but thinly veiled. Murray and the Council went down to Montreal and found 'the greatest enmity raging between the Troops and Inhabitants. ${ }^{20}$ To ease the tension, the 28th Regiment was sent to Quebec and the 2nd Battalion of the 60th Regiment replaced them at Montreal. ${ }^{21}$

Two days before their departure for Quebec, soldiers of the 28th attempted a rescue of the prisoners then in gaol. Captain David Skene pursued them first on foot and then in a commandeered carriolle. He overtook the soldiers and prisoners two and a half miles out of Montreal, drew his sword and 'call[ed] out as loud as he was able that he would run the first man through the Body that offered to pass him.' This threat seemed to have some effect, he said, but they still moved on though more slowly than before. He then made a pass at one of the men in the front and wounded him. This apparently intimidated the rest, the picket then arrived and Skene delivered the prisoners to the officer in charge. ${ }^{22}$

All this drama was for nothing though. No precautions were taken to secure the prisoners and they were broken out again the same night. In the company of three soldiers of the 28th Regiment, they gave themselves up the next day to the Commanding Officer at the fort at Chambly. They were conveyed to Quebec under military guard. ${ }^{23}$ They had successfully defied the civil authority in Montreal.

The 28th Regiment went to considerable trouble and risked a great deal to remove the accused men from the control of the civil authority in Montreal and place them under the control of the military and remove them to Quebec. Perhaps they wanted to keep the prisoners under their eye. ${ }^{24}$ The attack on Walker was planned quite deliberately; officers were certainly involved; it was not the impulse of the moment by a few drunken soldiers. Did the officers of the 28th Regiment see Thomas Walker as a symbol of the civil authority? That is to say, was this an overtly political act of defiance? Did they mean to overthrow civil authority by this action? Probably not. Walker was an irritant; they only meant to teach him a lesson, to mark him in a permanent and public way. But they were not restrained from attacking Walker by respect for his office or by submission to the civil authority he embodied. Even if the officers of the 28th did not intend to publicly declare their defiance of the civil authority, that is exactly what their actions menaced. Furthermore, when the regiment 'rescued' those accused of the assault, they again defied the civil power and refused to submit to its authority.

Nor did their superior officers show much respect or submission to the civil authority. 'The troops are not to be insulted and provoked,' Brigadier General Burton wrote to Governor Murray. Captain Mitchel- 
son warned that he could not answer for the regiment if they saw 'their fellow Soldiers dragged to Jail on the Slightest Pretences. ${ }^{25}$ Both these warnings contained an element of threat, a threat made more real by the recent assault on the Justice of the Peace. When Burton stated that he could not answer for the behaviour of the troops, Murray and the Council removed the 28th Regiment from the town of Montreal; they regarded the threat as real. The image created is of a dangerous and barely contained force that could all too easily break its bounds. That the military continued to protect the perpetrators of the assault represented a studied defiance of the civil authority and illustrates that legitimate authority was only precariously established in the colony.

\section{CAROLEE POLLOCK \\ University of Alberta}

\section{Notes}

1 Deposition of Martha Walker, 24 December 1764, PRO CO 42/4, ff. 216-17.

2 Thomas Ainslie to Governor James Murray, 13 December 1764, PRO CO 42/4, ff. 186-88.

3 The appointment of Francis Mounier, a Canadian Huguenot, to the Council shows that Canadiens were excluded from office not by reason of language or former allegiance but by religion.

4 James Murray to the Lords Commissioner for Trade and Plantations (hereafter Board of Trade), 23 August 1764. PRO CO 42/1, ff. 392-93.

5 As Paul Langford has argued, 'The political processes set in motion by the defeat of Stuart absolutism, the strategic and commercial implications of competition for trade and empire, the social consequences of demographic growth, urbanization, and industrialization, and the intellectual strains imposed by the impact of scientific enlightenment on conventional patterns of belief, all contributed to the sense of a society in turmoil. Yet the resulting transformation had to be accommodated by a mentality instinctively hostile to the concept of evolution, let alone revolution, in its modern progressive sense, and thoroughly self-conscious about its veneration for the past,' Public Life and the Propertied Englishman, 1689-1798 (Oxford: Clarendon, 1991), Preface, v.

6 Nor did they attempt to hold it by force. From a garrison of nearly 12,000 men in 1760 , the numbers quickly declined to less than 4,000 in 1763 and to only 1100 in 1766. Fernand Ouellet, "The British Army of Occupation in the St. Lawrence Valley, 1760-74: The Conflict between Military and Civil Society,' in Armies of Occupation, ed. Roy A. Prete and A. Hamish Ion (Waterloo: Wilfrid Laurier UP, 1984), p. 38. 
7 A.L. Burt told the story of The Old Province of Quebec in 1933; Hilda Neatby revisited the subject for the Centenary Series in 1966 in Quebec: The Revolutionary Age, 1760-1791. Burt wrote what one might call heroic history. He sought to understand the key figures of the day, Governors Murray, Carleton, Haldimand and the members of the ruling elite, in terms of their characters and personalities. His very thorough research and smooth narrative set a formidable precedent but he was also willing, in keeping with the standards of his time, to interpolate from the evidence he had, the motivations and emotions of his characters. And to evaluate them in quite personal terms: Governor James Murray was hot-tempered but sincere; Williams Conyngham, a lawyer in the colony, was a scoundrel; George Suckling and William Gregory were hopelessly inadequate to their roles as Attorney General and Chief Justice respectively. We no longer believe so readily in heroes and villains; perhaps we are less sure of the individual's capacity to shape history. We seek more complex explanations. In her account of the period in question, Hilda Neatby was caught up in the nationalist tensions of English Canada and French Canada, as befitted the decade in which she wrote. Her questions seem to be almost counterfactual. If the Governors, James Murray and Guy Carleton, had been more assiduous in their efforts to assimilate the French, if they had obeyed the instructions given them by the Privy Council, would Canada be wracked by conflict between French and English in the twentieth century? Philip Lawson has argued that it was their belief in the 'elastic' nature of the ancient constitution that enabled the British policy-making elite to offer significant concessions to Quebec's Catholics. It was the glory of the constitution that it could accommodate such changes. He argues that the Quebec Act of 1774 represented a significant movement towards toleration on the part of the British government. He concludes that 'those who supported the Quebec Act and grasped the nettle of toleration' in 1774 best deserve the title of radicals. A.L. Burt, The Old Province of Quebec (Minneapolis: U of Minnesota P, 1933); Hilda Neatby, Quebec: The Revolutionary Age, 1760-1791 (Toronto: McClelland and Stewart, 1966); Philip Lawson, The Imperial Challenge: Quebec and Britain in the Age of the American Revolution (Montreal and Kingston: McGill-Queen's UP, 1989); see also Philip Lawson, 'A Perspective on British History and the Treatment of Quebec,' Journal of Historical Sociology 3, 3 (1990): 253-71.

\section{Lord Hillsborough to Guy Carleton, 6 March 1768, PRO CO 43/8, ff.1-5.}

9 Although the Grand Jury included both English and French-speaking members, both Protestants and Catholics, it was the English-speaking merchants who dominated it and shaped its recommendations. A Memorial addressed to Governor Murray by Attorney General Suckling provides more insight into its calling. According to Suckling, Williams Conyngham had provided the Deputy Provost Marshal, with the list of men to be returned as Grand and Petty jurors. 'At the top of the first [list], were the Malcontents from not having been made Magistrates, and a few others, whose want of understanding, and whose situation in Life rendered them fit Tools of the Resentments of the former,' asserted Suckling. Memorial of Attorney General George Suckling to Governor James Murray, 3 May 1765, PRO CO 42/53, ff. 270-75.

10 Although the Justices of the Peace were drawn largely from the merchants, they were a fractious and competitive lot, with little respect for their fellows. See note 9 above.

11 Presentments of the Grand Jury of Quebec, 16 October 1764, British Library, Add. MSS. 32982, ff. 16-20. 
12 Statement by French Jurors in Reference to the Foregoing Presentments, Shortt and Doughty, Constitutional Documents, pp. 156-61.

13 Extract of a Letter from Governor Haldimand to Lord George Germain, 25 October 1780, PRO CO 42/10, f. 36v.

14 Order in Council, 18 October 1765, PRO CO 42/5, ff. 1-4.

15 Thomas Walker to Governor James Murray, 22 November 1764, PRO CO 42/4, f. 165.

16 Ibid., ff. 163-67.

17 Governor James Murray to the Board of Trade, 2 March 1765, PRO CO 42/53, f. 284.

18 Ibid., f. 281.

19 Brigadier General Ralph Burton to the Board of Trade, 1 February 1764, PRO CO 42/1, ff.163-172; Burt, Quebec, pp. 109-10.

20 Governor James Murray to the Board of Trade, 2 March 1765, PRO CO 42/53, f. 287.

21 Minute of Council, 3 January 1765, PRO CO 42/4, f. 176; Brigadier General Ralph Burton to James Goldfrap, 4 January 1765, PRO CO 42/4, ff. 174-75; Goldfrap to Burton, 4 January 1765, PRO CO 42/4, f. 176; Burton to Goldfrap, 5 January 1765, PRO CO 42/4, f. 175.

22 Deposition of Captain David Skene, 3 February 1765, PRO CO 42/4, ff. 196-97.

23 Information of Ensign Arthur Cole, 8 February 1765, PRO CO 42/4, ff. 204.

24 The author of an anonymous letter, signed Mathew Gospell, claimed that several men had been sent off by their officers to prevent their taking up the reward offered for information in the case. The reward offered was substantial and the author of the anonymous letter claimed that one of the prisoners was 'amind to turn Kings Witness after ye Rest is gan.' Anonymous Letter signed Mathew Gospell, 13 December 1764, PRO CO 42/4, ff. 186-88.

25 Captain James Mitchelson to Brigadier General Ralph Burton, 13 December 1764, PRO CO 42/4, ff. 183-84. 